The unique clinical features of the idiopathic AA type amyloidosis presented here would indicate that the tissue affinity of the amyloid is different from that of ordinary AA type and so are its biochemical properties. Study of similar cases, together with biochemical analysis of the amyloid, should clarify where this particular case stands in the broad spectrum of amyloidosis.

1 Meretoja J, Teppo L. Histopathological findings of familial amyloidosis with cranial neuropathy as principal ial amyloidosis with cranial neuropathy as principal
manifestation. Acta Pathol Microbiol Scand[A] 1971;79: manifestatic

2 Meretoja J. Familial systemic paramyloidosis with lattice dystrophy of the cornea, progressive cranial neuropathy, skin changes and various internal symptoms. Ann Clin Res 1969;1:314-24.

3 Loeffler KU, Edward DP, Tso MOM. An immunohistochemical study of gelsolin immunoreactivity in cornea amyloidosis. Am $\mathcal{F}$ Ophthalmol 1992;113:546-54.

4 Levy E, Haltia M, Fernandez-Madrid I, et al. Mutation in gelsolin gene in Finnish hereditary amyloidosis. 7 Exp Med 1990;172:1865-7.

5 Maury CPI, Kere J, Tolvanen $R$ de la Chapelle $A$ Finnish hereditary amyloidosis is caused by a single nucleotide substitution in the gelsolin gene. FEBS Lett 1990;276:75-7.

6 Nordborg C, Kristensson K, Olsson Y, Sourander P. Involvement of the autonomous nervous system in pri-
mary and secondary amyloidosis. Acta Neurol Scand mary and secon.

7 Wright JR, Calkins E, Humphrey RL. Potassium permanganate reaction in amyloidosis. A histologic method to assist in differentiating forms of this disease. Lab Invest 1977;36:274-81.

8 Pras M, Zaretzky J, Frangione B, Franklin EC. AA protein in a case of "primary" or "idiopathic" amyloidosis. Am $\mathcal{F}$ Med 1980;68:291-4.

9 Chambers RA, Medd WE, Spencer H. Primary amyloidosis. Qf Med 1958;NS27:207-26.

10 Muckle TJ, Wells M. Urticaria, deafness, and amyloidosis: A new heredo-familial syndrome. $Q \mathcal{F} \mathrm{Med} 1962$; NS31:235-48.

11 Van Allen MW, Frohlich JA, Davis JR. Inherited predisposition to generalized amyloidosis. Neurology 1969;19: 10-25.

12 Okayama M, Goto I, Tanaka T, Omae T. Familial primary amyloidosis with vitreous opacities and gastrointestinal symptoms. Report of a case. Rinsho Shinkeigaku 1974;14:293-9.

13 Goren H, Steinberg MC, Farboody GH. Familial oculoleptomeningeal amyloidosis. Brain 1980;103:473-95.

14 Haltia M, Ghiso J, Prelli F, et al. Amyloid in familial amyloidosis, Finnish type, is antigenically and structurally related to gelsolin. Am f Pathol 1990;136:1223-8.

15 Maury CPJ, Alli K, Baumann M. Finnish hereditary amyloidosis. Amino acid sequence homology between the amyloid fibril protein and human plasma gelsoline. FEBS Lett 1990;260:85-7.

\section{Bontius and Tulp on beriberi polyneuropathy}

In chapter 5 of his Observationes medicae, Nicolaus Tulp, stimulated perhaps by his teacher Jacobus Bontius, ${ }^{1}$ describes the beriberi of the East Indies. ${ }^{2}$ Bontius had served as a doctor in Batavia in 1627. His precise observations give the first recognisable picture of polyneuropathy (see also ${ }^{3}$ ):

. . . a kind of paralysis, or rather tremor; for it penetrates the motions and sensations of the hands and feet, indeed sometimes of the whole body . . movement and sensation particularly of the hands and feet are depraved, and they are weak; and in them is felt very often a tickling.

Unfairly judged by the modern genre, Tulp's punctuation is almost as idiosyncratic as his treatment, which the patient survived, perhaps because of his mother's good food.

Joost de Vogelaar, a youth fond of travelling, at that time in a particular part of the orient, was however in the region of Chloromandel, where the Sun sometimes burned so hotly that the natives sought to escape it, . . . this youth to shun such consuming heat, put himself on deck every day under the sky in the air ... they (his servants) bathed him with lots of cold water . . . the youth became sick, he had no power to control by his mind, obstipation as well as fluid in the skin, and the inordinate cold, repercussing excessively in the nerves produced that species of paralysis which is called in India Beriberi, or ovem (sheep).

Tulp inquired into the nature of the disease when his patient returned home:

For it fits in with a partial paralysis, his body was certainly drowsy and languid, and his limbs inert, and inactive, however by no means destitute of motion altogether and albeit sick he was little by little restored to health, gradually taking to food, not only to walk about, but he was permitted to sit in a chair to perform some slight movement, indeed in his dull limbs, now and then a movement was detected, and then that wandering sense of tickling which is accustomed to precede the flowing of animal spirits into the nerves . . . the patient regained his health by the familiar methods of his country and, since the treatment should have been by those very things prescribed specially for this disease from the Chief of the Indies to the Doctors . . . precious oil of the earth which is called Miniac Tennah Indis; and in the Island of Sumatra a trial of this Indian oil is made by us now in chilly disorders of the nerves and deep seated in the muscles.

Additional medication commended included:

. . . cathartics, then Guiac wood, sassafras and China root and externally an ointment partly from petroleum, partly indeed of castor oil, of wax, of the seeds of myristica, of cloves, of peppermint, and of rosewood .... and by the use of all these things, not however constantly, in this manner he was restored to a condition of perfect health.

JMS PEARCE 304 Beverley Road, Anlaby, Hull HU10 $7 B G, U K$

1 Bontius I. De medicina Indorum, libr. IV (Leyden: Patuliet, 1745;209). English translation. In: Classic descriptions of
disease, 3rd edn, Ralph H Major, ed. Oxford: Blackwell, $1945 ; 605$.

2 Tulp N. Observationes medicae. Ch V. Leyden: Vivie, $1716 ; 286$.

3 Pearce JMS. Robert Graves and multiple neuritis. $\mathcal{F}$ Neurol Neurosurg Psychiatry 1990;53: 113

See also p. 625 